\title{
Institutional Voids and Employment in Nigerian Agriculture
}

\author{
Adetunji Adeniyi, $\mathrm{PhD}$ \\ Tunji Adeniyi and Associates Limited, Lagos, Nigeria
}

\begin{abstract}
Governance has always been an issue in the economies of the Less Developed Countries (LDCs) of the world, and Nigeria is not an exception. The economy of Nigeria is managed through Ministries, Departments and Agencies (MDAs) delineated along sectoral lines. The agricultural sector is governed by the Federal Ministry of Agriculture and Rural Development that is responsible for formulating government polices to stimulate agricultural finance, production, storage, processing, value chain development and marketing. These polices are, in turn, expected to stimulate new investments, job creation, and employment in the sector. Time series secondary data covering 1981 to 2014 on the rebased Gross Domestic Product (GDP) and sectoral Gross Value Added (GVA) at 2010 constant basic prices, employment, wage rate, inflation rate and interest rate were collected from the National Bureau of Statistics and the Central Bank of Nigeria on the agricultural sector. The variables were collated and summarised into a table of data. The unit root test was carried out to test for stationarity of variables. Sectoral employment elasticities of growth were measured using Vector Error Correction Model (VECM) regression. Data was analysed using descriptive statistics and VECM at $\alpha_{0.05}$. Agriculture sectoral elasticity of employment was -0.02 , but it was not significant. Key informants in agricultural policy and agricultural value chains were then interviewed to determine why the job absorptive capacity of the agricultural sector was unexpectedly low, and the result, summarized with Khanna's Five-Context Model, pointed to institutional voids in the sector that must be addressed before the full employment generating potentials of the agricultural sector may be realised.
\end{abstract}

Keywords: Economic growth, Employment elasticity, Gross Value Added, Agricultural Sector, Institutional Voids.

DOI: $10.7176 / \mathrm{JESD} / 12-14-12$

Publication date:July $31^{\text {st }} 2021$

\section{Introduction}

Nigeria has continued to experience very high, rising and seemingly intractable levels of unemployment. Economists have postulated in literature that economic growth generates employment. It is against this backdrop that it was expected that the growth regime of 1981 to 2014 should have helped to reduce unemployment by generating a more than commensurate employment (Adeniyi, 2021).

Economic literature, however, acknowledges the advent of "jobless growth" whereby unemployment coexists with economic growth (Adeniyi, 2021).

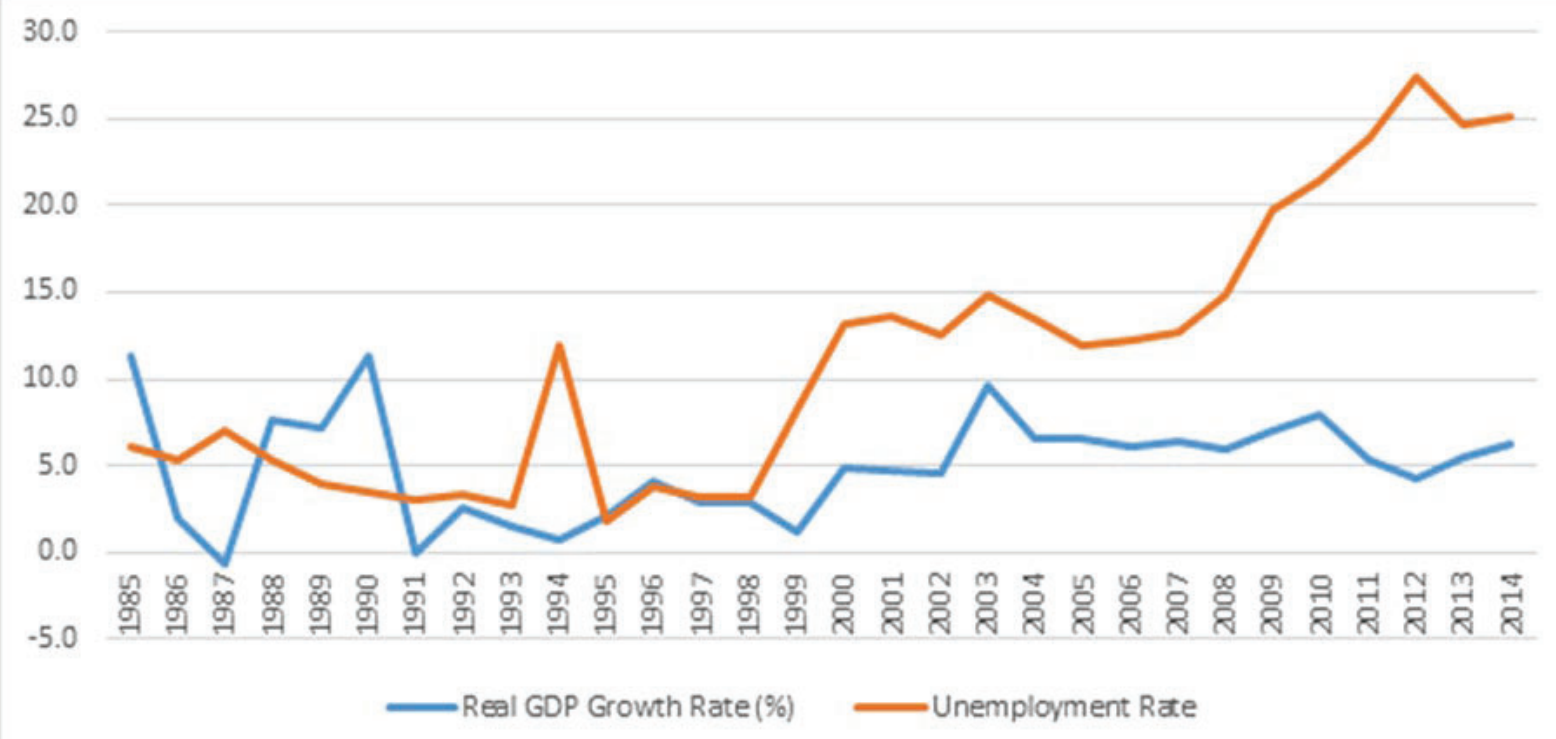

Source: Author's analysis of data collected from the National Bureau of Statistics

Figure 1: Rising Unemployment Co-existing with Economic Growth

According to the National Bureau of Statistics (2015) the rate of unemployment was 8.2 per cent by the end of the second quarter of 2015, despite the growth performance of the preceding years. The situation, which has 
further deteriorated due to subsequent economic decline, was recently accentuated by the outbreak of the COVID-19 pandemic, as unemployment rose to a record high of 27 per cent by the second quarter of 2020 (FGN, 2017; FGN, 2020; and, NBS, 2020).

Although, petroleum constitutes the major export product of Nigeria, accounting for about 95 per cent of government's external revenue, the Nigerian economy is still largely agrarian, accounting for more than 50 per cent employment (Adeniyi, 2019). In his "synthesis of the literature on employment creation in Nigeria's agriculture and agro-industries in the context of inclusive growth", Ogunleye, 2017, concluded that "there is a large untapped pool of employment opportunities in agriculture".

If Agriculture is still to be expected to continue to provide the bulk of employment in the economy, then policy makers should be interested in the job creating capacity of the sector and remove every impediment to job creation in the sector. The pertinent research question then is: what is the job absorptive capacity of the sector, and what attenuating governance issues in the agricultural sector must be addressed to enable the sector deliver its job creating potentials? Consequently, this study sets out to investigate the employment intensity of output growth in the agricultural sector and the institutional issues that must be addressed for the agricultural sector to deliver its job creating potentials?

\section{Literature Review}

\section{Meaning and effect of institutional voids}

Khanna and Palepu, 2010, described institutional void as the absence or the underdevelopment of business facilitating specialised intermediaries such as database vendors, quality certification firms, regulatory corporations, and control-enforcing mechanisms. It is the absence or the underdevelopment of formal institutions that support business activities. According to North, 1990, these are the humanly devised constraints that structure human interaction. Lack of attention for the context that the institutional arrangements hope to fill forms a basis of institutional voids. The less developed or developing countries are more characterised by institutional voids (Gao, C. et al, 2017; and, Dijk, P. v. 2018).

To survive and achieve long-term sustainability, enterprises operating in these political socio-economic environments must be able to respond to frequent unpredictable shocks - political instability, violence, macroeconomic fluctuations, and even war - without the benefit of specialized intermediaries that can analyze market information, facilitate transactions, and provide signals of credibility. Doing so can be very costly and difficult, and failure rates are, therefore, high (Khanna and Palepu, 1997; Khanna and Rivkin, 2001).

According to Scott, 2014, there are three pillars of institutional context; viz: cognitive, normative, and regulative. The regulative category provides a clearer connection to institutional voids. Regulative structures include laws which are connected to good regulatory corporations. These allow companies to orderly and properly do business. The absence or under-performance of such a physical, governance or soft structure would be an institutional void. Khanna et al, 2005, introduced a five context model to the analysis of institutional voids - political and social system, openness, product market, labour market, and capital market.

In order for a country's economy to function properly, it needs proper institutions - soft infrastructure (Khanna et al, 2010). Less Developed Countries (LDCs) usually have underdeveloped markets - capital, product and labour. This is consistent with Rehman, et al, 2020, that emerging base-of-the-pyramid (BoP) markets are frequently characterized by institutional voids. In developed countries, for example, there are many capital providers like venture capitalists and banks. In the LDCs, this is often more difficult, resulting in higher interest costs. Also, poorly functioning educational system and / or the absence of employment agencies, lead to bottlenecks, information asymmetry and increase in transaction costs, and make it difficult to extract value from resources.

\section{Agriculture and employment in Nigeria}

Agriculture is the lead contributor to employment in Nigeria, accounting for more than 50\% of employment. According to Adeniyi, 2019, The contribution of agriculture to employment reduced from $68.3 \%$ in 1981 to $53.5 \%$ in 2014 , while that of non-agriculture increased from $31.7 \%$ to $46.5 \%$ for the same period. However, agriculture still employed the greater number, contributing $31,241,000$ of the aggregate employment of $58,369,000$ in 2014.

There is an increasing marginal shift from the Agricultural sector in both absolute figures and the proportion of people working in the sector. Although, overall employment in Manufacturing, just as in Agriculture, also fell significantly between 2005 and 2014, Agriculture consistently had the largest negative contribution to the change in employment rate in Nigeria between 2005 and 2014. During the period, only Mining and Services sectors registered absolute employment growth. Employment contribution, however, shrank in all sectors, except in the services sector, where GDP contributions also more than doubled (Ajakaiye et al, 2016). In his "synthesis of the literature on employment creation in Nigeria's agriculture and agro- industries in the context of inclusive growth", Ogunleye, 2017, concluded that "there is a large untapped pool of employment opportunities in 
agriculture". According to Adeniyi (2019) employment is transitioning from production in the real sectors of Agriculture and Manufacturing to the Services sectors in Administration and Social Services, and Trade and Services sectors.

\section{Theoretical framework}

The national output of an economy, and by extension, any sector of the economy, is produced by combining labour input (demand for labor) with other factors of production in that economy or sector. The demand function for labor can be derived by assuming a constant elasticity of substitution (CES) production function and solving the marginal product of labor (MPL) equation for the labor input variable (Mkhize, 2015, and Adeniyi, 2019) as follows: -

$\mathrm{GVA}_{\mathrm{t}}=\mathrm{A}\left\{\alpha \mathrm{K}^{-\rho}+(1-\alpha) \mathrm{E}^{-\rho}\right\}^{-\eta /-\rho}$

where, $\mathrm{GVA}_{\mathrm{t}}=$ Gross Value Added (sectoral output)

$\mathrm{K}_{\mathrm{t}}=$ Capital (input) in year $\mathrm{t}$; $\mathrm{E}_{\mathrm{t}}=$ Employment/labor (input) in year $\mathrm{t}$.

$\mathrm{A}=$ Efficiency parameter; $\mathrm{A}>0$

$\eta=$ Returns to scale parameter; $\eta>0$

$\alpha=$ Distribution parameter; $0<\alpha<1$

$\rho=$ Extent of substitution (between $\mathrm{K}$ and E) parameter, $\rho>-1$, and related to elasticity of substitution; $\sigma=1 /$ $1+\rho$

The derivative of labor (i.e. marginal product of labor (MP $)$ from Equation (1) can be written as:

$\operatorname{dGVA} / \mathrm{dE}=\eta(1-\alpha) / \mathrm{A}^{\rho / \eta}$.GVA ${ }^{(1+\rho) / \eta} / \mathrm{E}^{\rho+1}$

The above $\mathrm{MP}_{\mathrm{L}}$ expression is solved for the $\mathrm{E}_{\mathrm{t}}$ input variable in order to derive the empirical labor (employment) demand function:

$\eta(1-\alpha) / A^{\rho / \eta} \cdot$ GVA $^{(1+\rho) / \eta}=\mathrm{E}_{\mathrm{t}}{ }^{\rho+1}$

[9]

$\left[\eta(1-\alpha) / A^{\rho / \eta} \cdot G^{(1+\rho) / \eta 1 / \rho+1}\right]$
$E_{t}=\left[\eta(1-\alpha) / A^{\rho / \eta} \cdot G E_{t}\right.$
$(1+\rho) / \eta 1 / \rho+1$

$=\left[\eta(1-\alpha) / \mathrm{A}^{\rho / \eta}\right]^{1 / \rho+1} \cdot \operatorname{GVA}^{(1+\rho / \eta)(1 / \rho+1)}$ $\beta 1$

$\mathrm{E}_{\mathrm{t}}=\beta_{0} \mathrm{GVA}$

where,

$\beta_{0}=\left[\eta(1-\alpha) / \mathrm{A}^{\rho / \eta}\right]^{1 / \rho+1}$

$\beta_{1}=(1+\rho / \eta)(1 / \rho+1)$

$\beta_{1}=1+\rho / \eta \cdot \sigma$

$\sigma$ (elasticity of substitution) $=1 / \rho+1$. However, if we log-transform Equation (3) above, we obtain the following employment function:

$\ln \mathrm{E}_{\mathrm{t}}=\ln \beta_{0}+\beta_{1} \ln \mathrm{GVA}_{\mathrm{t}}=\beta_{0}+\beta_{1} \ln \mathrm{GVA}_{\mathrm{t}}+\ldots \beta_{\mathrm{n}} \ln \mathrm{X}_{\mathrm{nt}}+\varepsilon_{\mathrm{t}}$

\section{Methodology}

The study examined the job absorptive capacity of the agricultural sector of the Nigerian economy. The employment intensity of agricultural gross value added growth between 1981 and 2014 was estimated. The secondary data used for the study were collected from the Central Bank of Nigeria (CBN), and the National Bureau of Statistics (NBS).

The variables collected, collated, analysed and presented were the figures of agriculture sectoral gross value 
added, agriculture sectoral employment, minimum wage rates, weighted average prime lending rates and inflation rates from 1981 to 2014. Estimation methodology of elasticity of employment, in deference to Ajilore and Yinusa (2011); Mkhize (2015); and, Adeniyi (2019) was used to analyse the data. Specifically, we used the Vector Error Correction Model (VECM). Key informants - operators and policy makers - were subsequently interviewed to ascertain the attenuating issues limiting the employment intensity / elasticity or employment generating potentials of agriculture. The results were then summarised for policy recommendations.

In order to estimate the sectoral employment elasticity of the agricultural sector of the economy and the elasticity of employment with respect to wage rate, inflation and user cost of capital in the economy during the period under review, a double-log linear regression equation was constructed for the parameters as follows:

$\ln L_{t}=\beta_{0}-\beta_{1} \ln W_{t}+\beta_{2} \ln r_{t}+\beta_{3} \ln G V A_{t}+\beta_{4} \ln \pi_{t}+T_{t}+\varepsilon_{t}$.

where, $\mathrm{t}=1, \ldots, \mathrm{n}$ years. The dependent variable, $L_{t}$, represents aggregate employment (formal and informal, public and private) in thousands of persons in the specific economic sectors, in year $t$.

The exogenous variables are:

$\mathrm{W}_{t}=$ minimum wage rate in time $\mathrm{t}$, measured in thousand Naira.

$\mathrm{r}_{t}=$ is the user cost of capital in time $\mathrm{t}$, represented by the weighted average prime lending rate in the economy.

$\pi_{\mathrm{t}}=$ inflation rate in time $\mathrm{t}$.

$\mathrm{GVA}_{t}=$ agriculture sectoral GVA in constant 2010 basic prices.

GVA_AGRI= Gross Value Added in the Agriculture sector in year t.

TIME $\left(T_{t}\right)=$ yearly time trend variable, where $t=1$ is year ended December, 1981 and

$\mathrm{t}=34$ is year ended December, 2014 .

$\varepsilon_{\mathrm{t}}=$ error term.

From the model, the equation to analyse is: -

EMP_AGRIC $=\mathrm{f}\left(\mathrm{GVA}_{-} \mathrm{AGRI}_{1}, W_{t}, r_{t}, \pi_{i}\right)$

Where:

$$
W_{t}=\text { Minimum Wage Rate in year } \mathrm{t}
$$

$r_{t}=$ WAPLR in year $\mathrm{t}$

$\pi_{t}=$ inflation rate in year $\mathrm{t}$

The above model postulates that employment of persons in the agricultural sector, will vary with gross value added in agriculture, and macroeconomic variables of wage rate, interest rate, and inflation rate, and that employment decisions by economic units in the agricultural sector are a function of previous year's information.

\section{Description of the variables}

Gross Domestic Product (GDP): Gross Value Added (GVA) is the value of goods and services produced in a sector. It is the output of the sector less intermediate consumption in that sector. In this study, these variables were obtained from the Nigerian National Bureau of Statistics (NBS). Yearly agricultural GVA series at 2010 constant basic prices were collected from NBS for the period 1981 to 2014. The series, which were in billions of Naira, were produced after the GDP rebasing exercise of 2014 which used 2010 as the base year. (Adeniyi, 2021).

Time trend: In a time-series analysis, time is a variable as the other variables and the relationships among them changes or stabilises over time. The lagging approach employed in the analysis took care of the time trend in determining /explaining employment level in the economy (Adeniyi, 2021).

Wages: Wage series were not available from the National Bureau of Statistics and other relevant organisations. Furthermore, NBS has not produced the re-based GDP using expenditure approach as of the time of this study. The latter would have been decomposed to obtain the wage component.

Although there are various concepts of wages we adopted the minimum wage in the economy for the following reasons which outweigh its limited variability since it does not change annually: It is more relevant to policy making; more determinable with exactitude; better known to everybody; more relevant to the economic strata where employment expansion is most desired, more relevant in determining the minimum financial welfare in the economy, etc. According to ILO (1970) the minimum wage represents the amount of compensation that an employer is required to pay wage earners for the work performed during a giving period, which cannot be reduced by collective agreement or by an individual contract. Minimum wage is, therefore, the lowest compensation that employers may legitimately pay to workers. This implies that it is the price floor below which a worker may not legally sell his labour services (Adeniyi, 2021).

Furthermore, recent debates among the three tiers of Government in Nigeria, the Labour Union, the Legislators, Non-Governmental Organisations, and Social Commentators on minimum wage did not only support this choice but seems to have heavy impact on the ethnic - or geo - political organisation, reorganisation and/or viability of the federating units of Nigeria (Eme and Ugwu, 2011; Ajimotokan and Obi, 2016; Buhari, 2016). It is more relevant in employment decision making particularly in the government sector that is very wage 
elastic, but expected to be employment intensive. For example, according to the Senate of the Federal Republic of Nigeria in its plenary of July 21, 2016, '27 states of the federation can no longer pay the salary of their workers.'

Other wage concepts are: average wages in the public sector, average wages in the private sector, average wages in the junior staff category and average salaries and emoluments of senior staff categories both in the public and private sectors (NECA, 2003; and, Adeniyi, 2021). For this study, minimum wage change history was obtained from NBS and from this; the minimum wage series was generated.

Interest rate: There are various concepts of the user cost of capital (Ajilore and Yinusa, 2011 Mkhize, 2015). This study used the Weighted Average Prime Lending Rate (WAPLR) of banks operating in the economy during the period, because it is more relevant considering that it affects every economic borrowing decision in the economy. It is subject to regular (weekly) professional determination and reviews at the Assets and Liability Management Committees (ALCOs) of all the banks operating in the economy. Besides, the determination of WAPLR also bears reference to the weighted average cost of generating loanable funds by lenders in the economy. Long-term lending, available only to prime bank customers, is consummated at around the Prime Lending Rate (CBN, 2015; and, Adeniyi, 2021).

Unemployment Rate: The data of unemployment rate was collected at the National Bureau of Statistics (NBS).

Inflation Rates: Annual Inflation Rates data were also collected from the National Bureau of Statistics.

GVA: Annual GVA for the agricultural sector were collected from the National Bureau of Statistics.

\section{Unit Root Test}

Time series data are most useful when they do not contain noise or unit root problems. However, frequently associated with time series data is the problem of noise. Consequently, it is necessary to test for and remove unit roots when and if they exist in any series. If they do, the noise must first be removed before proceeding with analysis in other that the results are not spurious, in other words, so that we can rely on the results for interpretation.

When there is no unit root or the noise has been removed, the series is said to be stationary. Several tests of stationarity have been developed to examine whether a series is stationary or non-stationary. If the series under analysis is stationary at level, this implies that the series contains no noise. Therefore, the series is said to be I( 0$)$. However, if the series being analysed is non-stationary in its level form, but stationary in the first difference form, then, it is said to be integrated of order 1 or I(1). Most time series can be classified as being integrated of order $d$, $\mathrm{I}(d)$. This means that the series must be differenced $d$ times to become stationary. The most common test of the stationarity of a time series is the Augmented Dickey-Fuller (ADF) test proposed by Engle and Granger in 1987 as follows (Adeniyi, 2021):

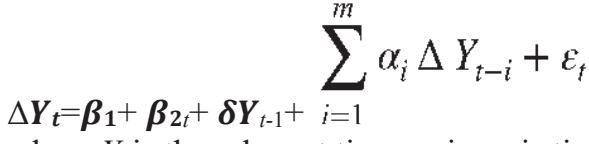

me trend, $\varepsilon_{t}$ a white noise error term; where

$\Delta Y_{t-1}=\left(Y_{t-1}-Y_{t-2}\right), \Delta Y_{t-2}=\left(Y_{t-2}-Y_{t-3}\right)$

The hypothesis of the ADF test will be specified as follows:

Null hypothesis: Ho: $\beta=0$

Alternative hypothesis: $\mathrm{H}_{1}: \beta<0$

If the null hypothesis is not rejected, then the series is non-stationary, but if it is rejected, it means the series is stationary or I(0). A time series is stationary when the process by which the data is generated is the same over time. That is, the series' mean, variance and covariance with lagged values of itself should not change with time. (Hansen and King, 1996; Mkhize, 2015; and, Adeniyi, 2019). According to Mkhize, (2015) ADF test tends to over-reject the null hypothesis when using too few lags and to reduce the degrees of freedom when there are too many lags. Song and Witt (2000) in their study of tourism demand modelling and forecasting, justified the importance of appropriate lag length for time series data. In determining the appropriate lag length for the ADF test in the study, Schwarz Information Criterion was used.

\section{Cointegration Test}

According to Stock and Watson (2017) when variables individually non-stationary are co-integrated, two (or more) variables may have common underlying stochastic trends along which they move together on a nonstationary path. For simple instances of few variables and one co-integrating relationship, an error-correction model (ECM) is the appropriate econometric specification. In this model, the equation is differenced and an error-correction term estimating the previous period's ( $t-1)$ deviation from long-run equilibrium is included.

The most common tests to investigate the number of common trends among the series in a VAR/VEC were developed and proposed by Johansen (1995). The approach is very similar to testing for unit roots in the 
polynomial representing an Auto Regression (AR) process. If we have $n$ I (1) variables that are modelled jointly in a dynamic system, there can be up to $n-1$ co-integrating relationships linking them. Stock and Watson (2017) thought of each co-integrating relationship as a common trend interconnecting some or all the series in the system. The co-integrating rank of the system is the number of such common trends, or the number of cointegrating relationships (Adeniyi, 2021).

To select the co-integrating rank $r$, a sequence of tests was performed. First, the null hypothesis of $r=0$ against $r \geq 1$ to investigate if there is at least one co-integrating relationship was tested. If and when $r=0$ is not rejected, then it was concluded that there were no common trends among the series, in which case, a VEC model is not needed. VAR is then simply used in the differences of the series.

If $r=0$ is rejected at the initial stage, then at least some of the series are co-integrated. Then, the number of co-integrating relationships is determined. The second step is to test the null hypothesis that $r \leq 1$ against $r \geq 2$. If the hypothesis of no more than one common trend is not rejected, then we estimate a VEC system with one cointegrating relationship.

If the hypothesis that $r \leq 1$ is rejected, then the hypothesis $r \leq 2$ against $r \geq 3$ is tested, and so on. $r$ is chosen to be the smallest value at which the null hypothesis that there are no additional co-integrating relationships is not rejected.

Johansen proposed many relevant tests that can be employed at each stage. The most common is the trace statistic, which was used in this study. The Stata command vecrank prints the trace statistic or, alternatively, the maximum-eigenvalue statistic.

\section{Vector Error Correction Model}

Vector error correction model (VECM) is the regression that takes into consideration the correction of the noise/unit root in the model as well as estimating the part of the noise that is being removed at each short run. (Stock and Watson, 2017). The software used for the regression analysis was Stata.

\section{A priori expectations}

The signs expected for the coefficients in the model are as follows:

$\mathbf{W}_{t}$ : negative. If and when the percentage change in nominal wages increases, it reduces employers effective demand for labour, given a constant budget constraint and vice-versa. (Dokpe 2001; Soto 2009; Baah-Boateng, 2013; and, Adeniyi, 2021).

$\mathbf{r}_{t}$ : positive or negative. If the interest rate increases, the demand by employers for capital decreases and the demand for consumer goods and services also decreases. The reduced demand for capital (that would become relatively more expensive) will reduce labour productivity and the depressed demand for consumer goods and services will decrease the derived demand for labour, vice versa. In these situations, employment would move in opposite directions to long term interest rates. However, in some industries capital may be a substitute for labour. In that wise, an increase in long term interest rates may depress the demand for capital and enhance the demand for labour, the substitute, vice versa. Consequently, long term interest rates would be a positive correlate of employment. (Malunda, 2012; Nangale, 2012; Baah-Boateng, 2013; Mkhize, 2015; and, Adeniyi, 2021).

$\pi_{\mathrm{t}}$ : positive or negative. The effect of inflation rate is expected to either be positive or negative. When and if the rate of inflation increases, the marginal revenue products of labour increases. As a consequence, there is an increase in the demand for labour by employers. On the other hand, an increase in inflation rate may reduce consumer demand for goods and services, thereby depressing the derived demand for labour as a factor of production. (Mkhize, 2015).

GVA $_{t}$ : positive. The growth of sectoral real GVA will lead to expanded derived demand for labour because employers will view real sector output growth as an indication of future expansion in demand for consumer final goods and services (Soto, 2009; Sodipe and Ogunrinola, 2011; Temitope, 2013; Mkhize, 2015; and, Adeniyi, 2021).

In order to make the model very useful for the analysis, equation (10) is log-linearised. The logarithmic functional form ensures that $\beta_{i}$ can be interpreted as elasticities (Koop, 2005 and Felipe and McCombie, 2015), where $\beta_{2}$ is the elasticity of employment with respect to user cost of capital, while holding all other things constant ceteris paribus. In the same manner, also $\beta_{3}$ is the elasticity of employment with respect to output. It estimates the proportional change in the number of labour employed for a proportional change in sectoral GVA, holding other factors constant, ceteris paribus. Consequently, a positive elasticity coefficient of 0.25 , for example, indicates that a percentage increase in GVA is associated with a quarter of a percentage increase in the number of people employed. The employment elasticity coefficients that will be calculated from the equation above imply that employment is a direct correlate of output (Soto, 2009; Sodipe and Ogunrinola, 2011; Temitope, 2013; and, Adeniyi, 2021). Consequently, the elasticity coefficients estimated for individual economic sectors are suggestive of the correlation between the number of persons employed and gross value added. 


\section{Findings and discussions}

Table 1 below presents the the result of the VECM estimation of equation 6. Column two of the table contains the estimated regression coefficients with respect to the variables in the first column. These coefficients also represent the elasticity of employment with respect to the respective variables. Thus, the elasticity of employment with respect to agricultural GVA is -0.02 , but it is not significant at $95 \%$ level of confidence. In the same manner, the estimated elasticities of employment with respect to wage rate, inflation rate and interest rate, respectively, are: $-0.00,-0.01$, and -0.01 , respectively, and the coefficients are, also, not significant at $95 \%$ confidence level.

Although, we may not be able to rely on these results for policy, because the coefficients are not significant, the interpretation of the result for agricultural GVA is that a one per cent change in agricultural GVA will lead to 0.02 per cent change in agricultural employment in the opposite direction. It also indicates that agriculture gross value added growth was achieved through productivity growth rather than the employment of more persons. Similarly, a one per cent change in wage rate, inflation rate and interest rate, respectively, will lead to -0.00 per cent, -0.01 per cent, and -0.01 per cent change in agricultural employment in the opposite direction.

Table 1: VECM estimation of employment intensity of agriculture sector in Nigeria. EMP_AGRIC $=\mathrm{f}\left(\mathrm{GVA} \_\right.$AGRI $\left., W_{t}, r_{t}, \pi_{t}\right)$

Vector error-correction model

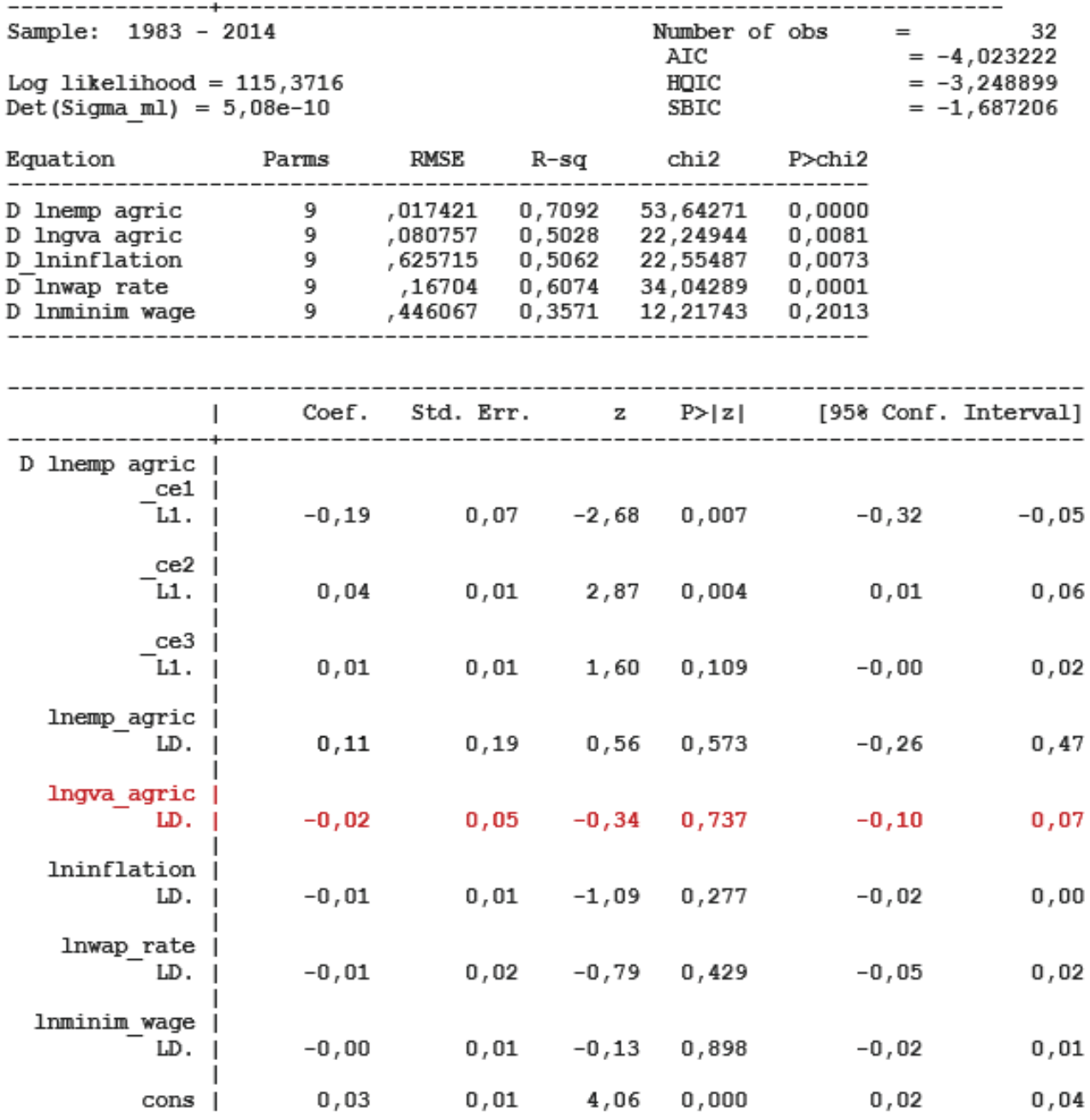

Source: Author's Analysis of Data collected from the National Bureau of Statistics

\section{Beyond Econometrics}

Given the unexpectedly low and insignificant employment elasticity of agriculture GVA, key informants in agricultural policy and agriculture value chains were interviewed to determine why the VECM estimated job absorptive capacity of the agricultural sector was unexpectedly low. The results, summarised below with Khanna's Five-Context Model of Institutional Voids, pointed to the institutional voids in the sector that must 
be addressed before the full employment generating potentials of the agricultural sector may be realized.

Interview with the Director General of Nigeria Employers' Consultative Association (NECA) On Employment Creation in the Agribusiness Value Chain: The impact of the external economies and the remedies

External economies here refer to importation of food (like rice) and Agribusiness / Agro-processing raw materials (like wheat, and juice concentrates) and the exportation of unprocessed farm produce. The impact of these is reduced domestic employment creation in the agribusiness value chains.

This anomaly can be reversed by tackling the following challenges currently facing the sector:

1) Inconsistent government policy, particularly, in the areas of backward integration and import substitution.

2) Inconsistent government policy on forward integration and Value added exports

3) Local content development in the agribusiness Value Chain is still at policy level, unlike in the oil and gas sector where it is already legislated into enforceable law.

4) The development of inter-linkages and Agricultural Value Chains is still poor. When fully developed, secondary products will constitute demand pull for primary products, leading to the creation of more jobs along the value chain.

5) Dumping of imported subsidized agricultural (foreign agricultural over-production) resulting in unfair competition with domestic producers operating under harsh and unsubsidized conditions.

6) Under-invoicing of agricultural imports which throws local producers out of competition.

Interview with the Executive Secretary, Nigerian Content Development and Monitoring Board.

The Nigerian Content Development and Monitoring Board is doing well in promoting the employment of indigenous men and materials by: -

1) generally Promoting the development the development and utilization of in-country capacities;

2) enhancing the quality of Nigerian jobs in the oil and gas industry throughout training and certification of indigenous human resources; and,

3 ) integrating the oil and gas communities into the oil and gas value chain.

Interview with the Managing Director/Chief Executive Officer and the Factory Operations Manager of a representative Nigerian Agribusiness - Fumman Agricultural Products Plc (Fumman)

Fumman belongs to the Food and Beverages sub-sector of the Agricultural Economic sector in Nigeria. There are over 100 (one hundred) participants in the organised private segment of this group, with a total annual group output of about N200.00 billion, and the Fruit Juices sub-group annual output of about N100.00 billion, produced mainly from tropical fruits. Fumman is responsible for about N4.00billion (or 4\%) of this.

Although Fumman's current capacity utilsation is between $35 \%-40 \%$, it sources about $40 \%$ of its raw materials locally, with own farm output accounting for about 50\% (or 20\% local content) produced from 386 hectares (or 965 acres) while other local sources account for the balance of $50 \%$ (I.e. $20 \%$ local content). The company has just acquired another/new farm land of about 140 hectares (or 350 acres). Though local yield per hectare is low compared to what obtains in its major import source (country of origin) of agricultural raw materials, Fumman, believes a mechanised out-grower scheme will enhance its local content program and provide jobs locally.

According to Fumman, the major challenges to increase to $100 \%$ local content are: high interest rates charged on loans by commercial banks; multiple taxes by the three tiers of governments; low level of mechanisation of farming; zero or low percentage subsidy on farm equipment importation; logistic problems (e.g. few good roads and ineffective rail transport system) which makes many local producers in the hinterland inaccessible, leading to high post-harvest losses of fresh fruits.

In Fumman's opinion, in order to address the current challenges, government policies should, generally, encourage farming; multiple taxes should be reviewed; mechanized farming should be encouraged by both private sector and government; and, government should build a network of good roads and rail system

\section{Interview with the Chief Executive Officer of a Major Indigenous Cocoa Processing Company Preferring Anonymity}

His company is a joint venture with some Chinese partners and has an installed capacity of 65 (sixty-five) metric tons of cocoa beans per annum. Employing about 600 people, they were capable of processing about $20 \%$ of Nigeria's output of cocoa beans into all the products range, including chocolate.

There are 10 (ten) operators in the cocoa grinding and processing product group. Their combined installed capacity can process more than the entire output of cocoa beans from Nigeria if the business environment is friendly.

Unfortunately, however, 3 (three) of the ten companies (including their own which employed 600 people) 
are currently closed down due to harsh business operating environment, including but not limited to: high cost of finance; and, high cost of raw materials aggravated by cut-throat competition from exporters of raw cocoa beans. In order to encourage local processing, value-added export and domesticate the job opportunities in cocoa processing, the position of the processing segment of Cocoa Association of Nigeria (CAN) is that government should: facilitate borrowing at much friendly rates of interest; and, impose export tax on the exportation of raw cocoa beans to encourage local processing (this option is preferred to the export expansion grant, which they are willing to trade off).

Interview with General Manager, Remedial Management/Loan Workout, Bank of Agriculture (BoA). Incorporated as Nigerian Agricultural Bank (NAB) in 1973, it was renamed Nigerian Agricultural and Cooperative Bank (NACB) in 1978. It was consolidated with People's Bank of Nigeria (PBN) and assumed the risk assets of Family Economic Advancement Programme (FEAP) to become Nigerian Agricultural Cooperatives and Rural Development Bank Limited (NACRDB) in 2000, and eventually renamed Bank of Agriculture (BOA) in 2010.

With the merger of the micro-finance development institutions, the mandate was expanded to include the provision affordable credit facilities to segments of the Nigerian society who have little access to the services of conventional banks while accepting savings deposits from customers and encouraging banking habits at the grass-roots. The performance of this role has been hampered by the following factors:

Weak funding, particularly tenured funds, capacity;

Inadequate capital

Inappropriate focus (majorly primary crops and animals);

Poor response time despite seasonality of rain-fed agriculture;

Cumbersome and less customer-friendly processes;

Access channel inadequacy (recent closure of some branches ill-advised;

Poor ICT and data integrity;

Channel inconvenience;

High real relative delivery cost; and,

Staff issues - competence, professionalism, motivation, training and development.

The bank is so weak that even the Central Bank of Nigeria, its parent institution, excluded it in the administration of its agricultural intervention loans (its core mandate) and also did not pay up its 40 per cent shareholding, therein. This was despite government advertised refocus on agriculture as a key pillar in the strategy to diversify the economic base of Nigeria, and BoA's obvious strength and advantages of sector institutional memory, and its growing collaboration with sub-national governments and potential collaboration with the Nigerian agribusiness group and their partner businesses.

\section{Interview with the Nigeria Youth Farmer Prize Winner and National Role Model}

According to the acclaimed youth farmer and government's "National Role Model", who is a qualified Medical Doctor (he actually started his working life practicing Medicine) the greatest challenges to youths in agriculture revolves around access to farmer-friendly agricultural loans and conditions - single digit interest rate, flexible collaterals (since most of them lack acceptable landed property) and appropriate tenors tailored to the lifecycle or project cash flow cycle of the enterprise. In his cassava sub-sector of the industry, he believes two critical success factors to sustainable profitability is improved stem cuttings mechanisation. Lately, also, insecurity and farm vandalisation by itinerant herdsmen have become key operations risks.

Interview with a "Woman-in-Agriculture" and Technical Assistant to the Minister of Agriculture.

According to the hands-on farmer, who was also most recently involved in agricultural policy formulation and administration, the three most critical problems facing women in agriculture are: land ownership issues, affordable and farmer-friendly credit facilities, insecurity on the farms and vandalisation of farm by itinerant herdsmen. Her company is into mixed farming in Ogun State, the contiguous state to Lagos. By the close of 2020, the company has "slowed down projects for safety and security reasons." The middle-aged woman rates insecurity above land tenure and credit, in that order. She is under intense family pressure to quit farming, altogether.

\section{Interview with Agribusiness Value Chain Directors at the Federal Ministry of Agriculture and Rural Development}

The agribusiness/product value chain directors at the Federal Ministry of Agriculture and Rural Development gave the following (Table 2) cursory estimates of job losses due to externalities or international exposures. 
Table 2: Estimated Equivalent job exports

\begin{tabular}{|l|l|l|l|}
\hline S/N & Particulars & Sugarcane & $\begin{array}{l}\text { Vegetable } \\
\text { oil }\end{array}$ \\
\hline $\mathbf{1}$ & Domestic demand (Metric Tonnes) & $\mathbf{1 , 4 5 0 , 0 0 0}$ & $\mathbf{1 , 7 0 0 , 0 0 0}$ \\
\hline $\mathbf{2}$ & Local production Metric Tonnes) & $\mathbf{1 0 0 , 0 0 0}$ & $\mathbf{1 , 3 0 0 , 0 0 0}$ \\
\hline 3 & Number of farmers involved in local production (persons) & $\mathbf{5 , 0 0 0}$ & $\mathbf{4 4 0 , 0 0 0}$ \\
\hline $\mathbf{4}$ & $\begin{array}{l}\text { Projected numbers of farmers required to meet domestic demand } \\
\text { (persons) }\end{array}$ & $\mathbf{7 1 , 4 2 9}$ & $\mathbf{5 7 5 , 3 8 5}$ \\
\hline $\mathbf{5}$ & Potential number equivalent jobs exported (persons) & $\mathbf{6 6 , 4 2 9}$ & $\mathbf{1 3 5 , 3 8 5}$ \\
\hline
\end{tabular}

Source: Analysis of data collected by the author at the Federal Ministry of Agriculture and Rural Development

\section{Sugarcane value chain}

According to the sugarcane value chain director in the Federal Ministry of Agriculture and Rural Development 5,000 farmers (increasing to 6,500 in 2015) were involved in sugarcane cultivation in 2014, producing 100,000 metric Tonnes of raw sugar (or about $6.9 \%$ ) of the total national requirement of 1,450,000 metric Tonnes of raw sugar in 2014.

The implication of this is that about 66,429 (about 93\%) of potential agricultural jobs have been externalized or exported. The value chain manager opined that apart from import tariff increases on raw sugar import, local production would be enhanced by the encouragement out-growers' schemes around existing irrigated mechanized plantations and the establishment of new plantations and out-growers' schemes.

\section{Vegetable oil value chain}

In the vegetable oil value chain, the story is not too different. Estimated domestic demand for vegetable oil is about 1,700,000 metric Tonnes per annum, while total local production from all sources are: (a) palm oil, 1,000,000 metric Tonnes produced by 390,000 farmers; (b) ground nut oil, 200,000 metric Tonnes, supplied by 40,000 farmers; and, (c) soybean oil, 100,000 metric Tonnes produced by 10,000 farmers.

From the above, about 440,000 farmers were involved in the production of vegetable oil in 2014, although there are possibilities that they engaged in mixed cropping or mixed farming. This suggests, back-of-theenvelope, that a total of about 135,385 similar jobs were exported to the countries that supplied the gap in domestic demand. According to the value chain manager, provision of improved seed/seedling varieties (for example earlier maturing, high yielding oil seed/seedling varieties), affordable and accessible farm credit, plantation farming, mechanised production and processing, stable policy, among many others, will improve local production.

Table 3: Khanna's Five-Context Model Analysis of Institutional Voids in Nigeria's Agriculture.

\begin{tabular}{|c|c|c|c|}
\hline $\mathrm{S} / \mathrm{N}$ & Context & Voids & Remedies \\
\hline 1 & $\begin{array}{l}\text { Political } \\
\text { and } \\
\text { social } \\
\text { Systems }\end{array}$ & $\begin{array}{l}\text { *Inconsistent government policy } \\
\text { on backward integration and import } \\
\text { substitution. *Lack of legislation on Local } \\
\text { content policies in agribusiness, unlike in } \\
\text { Oil and Gas sector. *Poor investment in } \\
\text { and development of the agribusiness value } \\
\text { chains. *Weak enforcement of regulations } \\
\text { on dumping and quarantine. * Insecurity. } \\
\text { *Weak production, processing, storage, } \\
\text { transport and marketing infrastructure. } \\
\text { *Ineffective / misdirected subsidies and } \\
\text { grants. }\end{array}$ & $\begin{array}{l}\text { *Turn agric polices into justice-able legislation. } \\
* \text { Invest in and develop agribusiness value } \\
\text { chains. *Enforcement of regulations on } \\
\text { dumping import- substitution and exportation } \\
\text { of raw produce, etc.) designed to promote local } \\
\text { production and employment generation. * }\end{array}$ \\
\hline 2 & Openness & $\begin{array}{l}\text { *Inadequate communication of } \\
\text { government policies with agribusiness } \\
\text { operators. *Opacity in the administration } \\
\text { of government support - financial grants, } \\
\text { subsidies, mechanization grants, } \\
\text { concessional loans, etc. *Blackout on } \\
\text { agricultural innovations. *Racketeering in } \\
\text { government support programmes. }\end{array}$ & $\begin{array}{l}\text { *Institute effective and efficient agribusiness } \\
\text { extension system and improve the interaction } \\
\text { between farmers and the researchers stations. } \\
\text { * Decentralize government intervention } \\
\text { programmes to the reach of the intended } \\
\text { beneficiaries. *Professionalize the Ministry of } \\
\text { Agric and Rural Development and resource } \\
\text { with staff that are committed to achieving } \\
\text { results for the sector. }\end{array}$ \\
\hline
\end{tabular}




\begin{tabular}{|c|c|c|c|}
\hline $\mathrm{S} / \mathrm{N}$ & Context & Voids & Remedies \\
\hline 3 & $\begin{array}{l}\text { Product } \\
\text { market }\end{array}$ & $\begin{array}{l}\text { *Dumping of substandard, and sometimes } \\
\text { injurious, food and agrochemicals. } \\
\text { *Unfair competition with subsidized, } \\
\text { substandard, expired products. *Under- } \\
\text { invoicing and duty evasion on imported } \\
\text { agricultural products. *Information } \\
\text { asymmetry on input and product } \\
\text { availability }\end{array}$ & $\begin{array}{l}\text { *Enforcement of standards at the ports of entry } \\
\text { on imported items. *Prevention of dumping and } \\
\text { unfair competition. *Institute a more committed } \\
\text { effective customs and excise enforcement } \\
\text { backed by the enlightenment of officers on the } \\
\text { full economic consequences of compromise. } \\
\text { *Institute an effective and efficient Commodity } \\
\text { exchange resourced with professionals }\end{array}$ \\
\hline 4 & $\begin{array}{l}\text { Labour } \\
\text { Market }\end{array}$ & $\begin{array}{l}\text { *Illiteracy and knowledge-gap in } \\
\text { agricultural innovations. } \\
\text { *Ageing of the existing primary producers } \\
\text { (farmers). } \\
\text { *Defective agricultural education that } \\
\text { places less emphasis on the practical } \\
\text { exposure of students. }\end{array}$ & $\begin{array}{l}\text { *Emphasize hands-on practical training and } \\
\text { agribusiness in agricultural education. } \\
\text { *Establish more schools of agriculture. } \\
\text { *Institute effective and efficient agribusiness } \\
\text { extension services. *Incentivize agribusiness to } \\
\text { encourage the youth, graduates of agriculture } \\
\text { and women into the sector. * Establish many } \\
\text { well-resourced (with all modern amenities to } \\
\text { encourage and attract the youth) farm } \\
\text { settlements and model farms across the country. }\end{array}$ \\
\hline 5 & $\begin{array}{l}\text { Capital } \\
\text { market }\end{array}$ & $\begin{array}{l}\text { *Lack of access to loans of the right tenor } \\
\text { and interest rate. *Stringent, not } \\
\text { agriculture-friendly loan conditions, } \\
\text { sometimes excluding youth and women. }\end{array}$ & $\begin{array}{l}\text { *Recapitalize and commercialize Bank of } \\
\text { Agriculture (BoA). *Resource BoA with } \\
\text { professional agricultural finance/economics } \\
\text { experts. *Move all government agricultural } \\
\text { intervention programmes from the Central } \\
\text { Bank to BoA. *Modernize, computerize and } \\
\text { ramp-up agricultural lending programmes at } \\
\text { BoA. } \\
\text { *Incentivize other lending institutions to ramp- } \\
\text { up agricultural loans of the appropriate terms. }\end{array}$ \\
\hline
\end{tabular}

\section{Conclusions and Recommendations}

Researchers and policy makers have been unambiguous on the present and the expected future roles of agriculture in employment generation in Nigeria. However, they are equally apprehensive that the expected future role may not be achieved by default, giving the evidences of the last few decades, whereby, agriculture has continued to account for declining proportion of employment in the economy.

In this study, econometric estimation indicates the unexpectedly low employment elasticity of agricultural value added, and suggests that output growth in the agricultural sector during the period under review was achieved through productivity increases rather than the employment of more persons. Providing noneconometric reasons for this situation, participants in the agricultural sector are unanimous on the existence of institutional voids or impeding factors in the sector, which if corrected will lift the sector to its full potentials in job creation.

\section{References}

Adeniyi, A. 2021. Designing a framework for employment-growth targeting in Nigeria. Journal of Asia Development. ISSN 2377 - 9594.

Adeniyi, A. 2019. Economic growth and employment nexus in Nigeria's agricultural and non-agricultural sectors (1981-2014). PhD Thesis in the Department of Agricultural Economics (in Press).

Ajakaiye, O. et al. 2016. Understanding the Relationship Between Growth and Employment in Nigeria. Africa Growth Initiatives at Bookings. Development Policy Research Unit, United Nations University, UNUWIDER. May.

Ajilore, T. and Yinusa, O. 2011. An Analysis of Employment Intensity of Sectoral Output Growth in Botswana. Southern Africa Business Renew, 15(2):26-42.

Ajimotokan, O. and Obi, P. 2016. Government and NLC, set up technical committee on minimum wage and pump price of petrol. Back page, Thisday Newspaper, May 26.

Baah-Boateng, W.2013. "Determinants of Unemployment in Ghana," African Development Review, 21(4):385399, December, Wiley Publication.

Buhari, M. 2016. 27 States have difficulties paying salaries. Punch Newspapers, July 24.

Dijk, P. v. 2018. Dealing with institutional voids in emerging markets: A small and medium sized enterprise perspective. Unpublished Master of Business Administration (Strategic Management) Thesis. Radboud 
Universiteit, Nijmegen.

Dopke, J. 2001. The Employment Intensity of Growth in Europe. Kieler Arbeitspapiere. No. 1021. Available at: http://hdl.handle.net/10419/17746.

Eme, O. I. and Ugwu, S. C. 2011. Governors and the new minimum wage act: implications for state-labour relations in Nigeria. Arabian Journal of Business and Management Review vol 1 No 3.

FGN (Federal Government of Nigeria). 2020. Bouncing Back: Nigeria Economic Sustainability Plan.

FGN (Federal Government of Nigeria). 2017. Economic recovery and growth plan, 2017-2020. Ministry of Budget and National Planning. February.

Felipe, J. and McCombie, J. S. L. 2015. Aggregate Production Function and the Measurement of Technical Change 'Not Even Wrong'. Edward Elgar Publishing Ltd. ISBN 978184064064255.

Gao, C., Zuzul, T., Jones, G., and Khanna, T. 2017. Overcoming Institutional Voids: A Reputation-Based View of Long Run Survival. Harvard Business Review. Working Paper 17-060.

Hansen, P. and King, A. 1996. The determinants of health care expenditure: A co-integration approach. Journal of Health Economics Volume 15, Issue 1, February, Pages 127-137.

ILO. 1970. General Survey of the Reports of the Minimum Wage Fixing Convention. No. 131, and the Minimum Wage Fixing Recommendations No. 135. International Labour Conference, $103^{\text {rd }}$ Session, 2014. ILC.103/III/1B.

Johansen, Soren. 1995. Likelihood-Based Inference in Co-integrated Vector Autoregressive Models. Oxford: Clarendon Press.

Khanna, T., and Palepu, K. G. 2010. 'The nature of institutional voids in emerging markets', in T. Khanna and K. G. Palepu (eds), Winning in Emerging Markets: A Road Map for Strategy and Execution: 13-26. Boston: Harvard Business Press.

Khanna, T., Palepu, K. G., and Sinha, J. 2005. 'Strategies that fit emerging markets'. Harvard Business Review, June: 4-19.

Khanna, T., and Palepu, K. G. 2005. Emerging giants: Building world-class companies in emerging markets. Harvard Business Review, June: 37-45.

Khanna, T. and Rivkin, J.W. 2001. Estimating the Performance Effects of Business Groups in Emerging Markets. Strategic Management Journal, 22, 45-74.

Khanna, T., and Palepu, K. G. 1997. Why Focused Strategies May Be Wrong for Emerging Markets, Harvard Business Review, July-August: 41-51

Koop, G. 2005. Analysis of Economic Data, 2nd edition. John Wiley \& Sons.

Malunda, D. 2012. Employment Intensity of Non-Agricultural Growth in Rwanda: Analysing the Links between Growth, Employment and Productivity in Rwanda. Institute of Policy Analysis and Research. Rwanda.

Mkhize, N. 2015. The Sectoral Employment Intensity of Growth in South Africa: 2000:01 - 2012:04. School of Economic Sciences, University of South Africa. P.O. Box 392, Pretoria, 0003. South Africa.

Nangale, G. 2012. The Role of the State in Economic Development: Employment Challenges in Eastern Africa The case of Tanzania. A Country Paper Presentation at the Friedrich Ebert Stiftung (FES) Eastern African Conference on Employment Policies in Nairobi, Kenya. September 24 - 25.

National Centre for Economic Management and Administration (NCEMA) (a\&b). 2004. Understanding Structural Adjustment Programme in Nigeria. A Draft Report Submitted to Global Development Network. Presented at the Workshop on Understanding Reform, New Delhi, India. January 25-26.

NBS. 2020. Unemployment and Underemployment Report.

NBS. 2015. Nigerian Gross Domestic Product Report, Quarter Two. Issue 6.

NBS. 2015. Unemployment / Under-employment Watch.

Nigeria Employers' Consultative Association (NECA). 2003. Inter Industrial Survey.

North, D. C. (1990). Institutions, institutional change, and economic performance.

Cambridge, MA: Harvard University Press.

Ogunleye, E. K. 2017. Synthesis of the literature on employment creation in Nigeria's agriculture and agroindustries in the context of inclusive growth. Partnership for African Social and Governance Research. Available at: http://www.pasgr.org/wp-content/uploads/2017/07/Synthesis-of-the-Literature-onEmployment-Creation-in-Nigeria's-Agriculture-and-Agro-Industries-in-the-Context-of-InclusiveGrowth.pdf.

Rehman, A. u.; Jajja, M S. S.; Khalid, R. U.; Seuring, S. 2020. The impact of institutional voids on risk and performance in base-of-the-pyramid supply chains. The International Journal of Logistics Management. Volume 31 Issue 4, ISSN: 0957-4093. 13 October.

Scott, W. R. 2014. Institutions and organizations - ideas, interests and identities. Fourth edition. Thousand Oaks, CA. Sage.

Sodipe, O. A. and Ogunrinola, O. I. 2011. Employment and Economic Growth Nexus in Nigeria. International Journal of Business and Social Science, Vol. 2 No. 11. 
Song, H. and Witt, S. F. 2000. Tourism demand modelling and forecasting: Modern econometric approaches. Oxford, Pergamon.

Soto, R. 2009. Dollarisation, Economic Growth and Employment. Economic Letters, 105(1):42-45.

Stock, J. H. and Watson, M. W. 2017. Introduction to Econometrics. Update. Third Edition. Pearson Education.

Temitope, L.A.L. (2013). Does Economic Growth Lead Employment in South Africa? Journal of Economics and Behavioural Studies, Vol. 5, No. 6, pp. 336-345. 